HANNA SULEWSKA ${ }^{1}$, WIESŁAW KOZIARA ${ }^{1}$, GRAŻYNA SZYMAŃSKA ${ }^{1}$, ALICJA NIEWIADOMSKA ${ }^{2}$, KATARZYNA PANASIEWICZ ${ }^{1}$, KAROLINA RATAJCZAK ${ }^{1}$

${ }^{1}$ Department of Agronomy

Poznań University of Life Sciences

${ }^{2}$ Department of Agricultural Microbiology

Poznań University of Life Sciences

\title{
RESPONSE OF SPRING BARLEY TO PRP SOL APPLICATION AS A COMPLEX OF MINERAL INDUCER PROCESS (MIP)
}

\author{
REAKCJA JĘCZMIENIA JAREGO NA STOSOWANIE PRP SOL \\ JAKO KOMPLEKSU BIOAKTYWNYCH ZWIĄZKÓW MINERALNYCH (MIP)
}

\begin{abstract}
Summary. The aim of the application of a PRP SOL complex of MIP bioactive compounds is to improve the soil characteristics by unblocking the potential of the nutrients in the soil and making them available to plants. This fertilizer is used for soil fertilization rather than crop nutrition. The research focused on evaluation of the yield of spring barley after the application of the PRP SOL technology in the fields of the Research and Education Center Gorzyń, at the Experimental Station in Złotniki, in 2007 to 2011. The purpose of the research was to compare the effects of spring barley fertilization technology by applying a complex of MIP bioactive compounds in the form of a PRP SOL fertilizer with the standard technology applying phospho-potassium fertilization. The five years of the research led to the conclusion that the traditional fertilization of spring barley plantations with phosphorus and potassium can be replaced with the technology applying the MIP complex without grain yield losses. However, the yield was not stable between years. In one of the five research years (2007) there was a significant increase (by $3.7 \mathrm{dt} \cdot \mathrm{ha}^{-1}$ ), and in another (2010) a significant decrease (by $3.2 \mathrm{dt} \cdot \mathrm{ha}^{-1}$ ) as a result of fertilizer use. The PRP SOL fertilizer may be particularly useful for malting barley due to the favourable increase in the share of lush grain fractions (larger than $2.5 \mathrm{~mm}$ ) and simultaneous decrease in the share of smaller grains and due to the fact that the weight of $1 \mathrm{hl}$ tends to decrease whereas the thousand grain weight tends to increase.
\end{abstract}

Key words: PRP SOL fertilizer, spring barley, grain yield, LAI, SPAD, yield components 
Sulewska, H., Koziara, W., Szymańska, G., Niewiadomska, A., Panasiewicz, K., Ratajczak, K. (2016). Response of spring barley to PRP SOL application as a complex of mineral inducer process (MIP). Nauka Przyr. Technol., 10, 2, \#17. DOI: $10.17306 /$ J.NPT.2016.2.17

\section{Introduction}

The content of potassium in Polish soils ranges from $0.01 \%$ to $2 \%$ (from 300 to $60000 \mathrm{~kg}$ potassium per $1 \mathrm{ha}$ ), whereas the content of phosphorus ranges from $0.01 \%$ to $0.2 \%$ (from 300 to $6000 \mathrm{~kg}$ phosphorus per $1 \mathrm{ha}$ ) (Dobrzański and Zawadzki, 1995). However, these components are not available for plants. Otherwise, fertilization with these nutrients could have been abandoned many years ago. Ram et al. (2015) pointed out that only $0.1 \%$ of the total phosphorus exists in a soluble form available for plant uptake because of its fixation into an unavailable form. Phosphorus can be found in the forms which are unavailable for plants, such as $\mathrm{FePO}_{4}$ and $\mathrm{AlPO}_{4}$, whereas potassium is blocked in loamy minerals. Spring barley has relatively low demand for phosphorus and potassium, but the appropriate amount is necessary for the proper growth and development of plants. The soil pH strongly influences the yield of spring barley. According to American studies, when $\mathrm{pH}$ drops to 5.2, 5.1, 5.0, 4.9 and 4.8, the yield decrease by 7\%, $17 \%, 26 \%, 36 \%$ and $46 \%$, respectively can be expected (Mahler and Guy, 2007). The optimal $\mathrm{pH}$ of soil for the development of this species is 5.3 or higher. The aim of the application of a PRP SOL complex of MIP bioactive compounds is to improve the soil characteristics by unblocking the existing potential of the components in the soil and making them available for plants nutrition (Hüttl and Fischer, 2004). The manufacturer declares that the PRP SOL is used to fertilize the soil rather than plants. By its structurebuilding effect on the soil and by the stimulation of biological life the fertilizer gives plants access to enormous amounts of nutrients, which have been unavailable so far (Lipski, 2008). The supportive substances in it, including the substances containing suitable microorganisms, enable appropriate control of the processes taking place in the soil. Hence the expectations, that the PRP SOL fertilizer may replace the phosphorus and potassium fertilization in all farmlands. If applying this type of fertilization would play the same role as given by the manufacturer it could be a good alternative for mineral fertilization in organic farming. Maikštènienè and Maikštėnienè (2011) pointed out that the problem of phosphorus shortage, especially on clay loam cambisol of glacial lacustrine origin becomes most apparent, since low phosphorus content is a genetic characteristic of this soil type.

The granulate containing $32 \% \mathrm{CaO}$ and $8 \% \mathrm{MgO}$ is the active substance in the PRP SOL, which means that it is a calcium fertilizer with magnesium added, which also contains $3.5 \%$ of sodium $(\mathrm{Na})$ and $3-5 \%$ of prefixes, with which 48 trace elements which are necessary for the normal growth and development of plants are entered into the soil (Krzywy, 2008). The fertilizer can be used for all crops grown in the conventional and organic farming system, where the annual doses range between $150-300 \mathrm{~kg}$ per 1 ha.

The aim of the research was to compare the effects of the spring barley fertilization technology applying a complex of MIP bioactive compounds in the form of a PRP SOL fertilizer with the standard technology applying phosphorus-potassium fertilization.

The research hypothesis assumes that the replacement of phosphorus and potassium fertilization with the PRP SOL does not lead to reducing grain yield and does not disturb the growth and development of barley plants. 
Sulewska, H., Koziara, W., Szymańska, G., Niewiadomska, A., Panasiewicz, K., Ratajczak, K. (2016). Response of spring barley to PRP SOL application as a complex of mineral inducer process (MIP). Nauka Przyr. Technol., 10, 2, \#17. DOI: $10.17306 /$ J.NPT.2016.2.17

\section{Material and methods}

\section{Field trial}

From 2007 to 2011 at the Experimental Station in Złotniki, belonging to Research and Education Center Gorzyń, Poznań University of Life Sciences, Poland, there were field experiments conducted. The effects of a complex of MIP bioactive compounds applied in the PRP SOL fertilizer in the growing of 'Antek' spring barley cultivar was evaluating. The GPS coordinates of the experiment were: N 52²9.193', E 016 $20.569^{\prime}$. Spring barley was grown in a five-year crop rotation after potatoes, which were planted at the station without manure, where 350 seeds per $1 \mathrm{~m}^{2}$. The experiments were replicated four times in the field, applying the randomized block design. The research factor was the application of the PRP SOL fertilizer, which was applied into the soil in spring, after the sowing of barley, at annual dose of $220 \mathrm{~kg} \cdot \mathrm{ha}^{-1}$ (Table 1). The area of the plots for harvest equaled to $64 \mathrm{~m}^{2}$. Apart from the fertilization, all agrotechnical procedures were conducted according to the rules of correct spring barley agrotechnology. The soil of the experimental field is maintained in a good culture and it is classified as lessive earth soil. According to the soil agricultural usefulness, it belongs to complex 4 (very good rye complex), and according to the soil taxonomy, it belongs to class IVa (FAO, 2006). The content of $\mathrm{P}_{2} \mathrm{O}_{5}$ and $\mathrm{K}_{2} \mathrm{O}$ in the soil of the experimental field equaled to 14.9 and $13.8 \mathrm{mg}$ per $100 \mathrm{~g}$ of soil, respectively and was classified a medium level. The soil $\mathrm{pH}$ was 5.5.

Table 1. Fertilization of experimental objects with dose of PRP SOL, phosphorus, potassium and nitrogen $\left(\mathrm{kg} \cdot \mathrm{ha}^{-1}\right)$

Tabela 1. Nawożenie obiektów doświadczalnych dawką PRP SOL, fosforu, potasu oraz azotu $\left(\mathrm{kg} \cdot \mathrm{ha}^{-1}\right)$

\begin{tabular}{|l|c|c|c|c|}
\hline $\begin{array}{c}\text { Treatment } \\
\text { Kombinacja }\end{array}$ & PRP SOL & P & K & N \\
\hline Control - Kontrola & 0.0 & 34.9 & 99.6 & 40.0 \\
PRP SOL & 220.0 & 0.0 & 0.0 & 40.0 \\
\hline
\end{tabular}

$\mathrm{P}$ - potassium salt $60 \%, \mathrm{~K}$ - triple superphosphate $46 \%, \mathrm{~N}$ - ammonium nitrate $34 \%$.

$\mathrm{P}$ - 60-procentowa sól potasowa, $\mathrm{K}$ - 46-procentowy superfosfat, $\mathrm{N}$ - 34-procentowa saletra amonowa.

\section{Determination of physical traits and quality attributes}

At the end of the tillering stage and at the beginning of the stem elongation stage (BBCH 30$)$ the soil compaction was measured by means of a manual Eijkelkamp penetrometer, and since 2010 an Eijkelkamp Penetrologger SN penetrometer was used. At the end of the anthesis (BBCH 69) the leaf area index (LAI) was measured with a SunScan Canopy Analysis System type SS1 meter; the leaf greenness index (SPAD) was measured on the flag leaf with an N-Tester (Hydro). Additionally, the height of the plants was measured. At harvest time of barley the hectolitre weight and grain moisture 
Sulewska, H., Koziara, W., Szymańska, G., Niewiadomska, A., Panasiewicz, K., Ratajczak, K. (2016). Response of spring barley to PRP SOL application as a complex of mineral inducer process (MIP). Nauka Przyr. Technol., 10, 2, \#17. DOI: $10.17306 /$ J.NPT.2016.2.17

were estimated with an electronic moisture meter with built-in scales. Then grain yield, number of spikes per square meter, number of grains per spike and thousand grain weight (TGW) were evaluated. The grains were fractioned by means of Vogel sieves, for all the treatments, with samples weighing $300 \mathrm{~g}$. The sieves considered following diameters: $2.75,2.5$ and $2.25 \mathrm{~mm}$. The quality parameters were estimated at the laboratory of the Department of Agronomy, Poznań University of Life Sciences, Poland.

\section{Meteorological conditions}

The hydrothermal coefficient of water supply was calculated for individual years according to Selyaninov's method based on the data from the meteorological station in Złotniki. The following formula was applied:

$$
\mathrm{K}=\frac{\mathrm{M}_{\mathrm{o}} \times 10}{\mathrm{D}_{\mathrm{t}} \times \text { days }}
$$

where:

$\mathrm{K}$ - the hydrothermal coefficient for individual months,

$\mathrm{M}_{\mathrm{o}}$ - total monthly precipitation,

$\mathrm{D}_{\mathrm{t}}$ - mean daily temperatures in a particular month.

\section{Statistical analysis}

The results of the five-year research were analysed statistically according to the procedure for orthogonal factorial experiments. The least significant difference (LSD) was verified with Student's $t$ test at a level of $\mathrm{P} \leq 0.05$. For the analysed traits the characteristics of variation were also determined, such as standard deviation (SD), coefficient of variation $(\mathrm{CV})$, and minimum and maximum values. Apart from that, the correlation and linear regression analysis were used. The significance of the Pearson linear correlation coefficients under investigation was estimated at a confidence level $\alpha=0.05$ (*significant difference) and $\alpha=0.01$ (**very significant difference).

\section{Results and discussion}

The research was conducted in the years which differed in the pattern of weather conditions during the vegetation period of spring barley. Šarauskis et al. (2013) pointed out that climatic conditions and plant characteristics in different countries of the world differ greatly, so it is desirable to present its influence on spring barley vegetation also in our region. Table 2 shows Selyaninov's hydrothermal coefficients, which indicate the periods of drought, semi-drought and relatively good humidity in individual years of the research. It is necessary to stress the occurrence of months with very low precipitation: April 2007, May and June 2008, April 2009 and June 2010 and a three-month spring drought period, which continued until 30 June 2011 and which was followed by very heavy rainfall in July. 
Sulewska, H., Koziara, W., Szymańska, G., Niewiadomska, A., Panasiewicz, K., Ratajczak, K. (2016). Response of spring barley to PRP SOL application as a complex of mineral inducer process (MIP). Nauka Przyr. Technol., 10, 2, \#17. DOI: $10.17306 /$ J.NPT.2016.2.17

Table 2. Hydrothermal coefficient K of water supply according to Selyaninov

Tabela 2. Współczynnik hydrotermiczny K zabezpieczenia w wodę według Selianinowa

\begin{tabular}{|c|c|c|c|c|c|}
\hline \multirow{2}{*}{$\begin{array}{c}\text { Month } \\
\text { Miesiąc }\end{array}$} & \multicolumn{5}{|c|}{ Years - Lata } \\
\cline { 2 - 6 } & 2007 & 2008 & 2009 & 2010 & 2011 \\
\hline III & 3.1 & 3.3 & 4.1 & 2.6 & 1.1 \\
IV & 0.2 & 2.6 & 0.4 & 1.2 & 0.1 \\
V & 1.7 & 0.2 & 2.0 & 3.6 & 0.4 \\
VI & 0.7 & 0.1 & 2.6 & 0.5 & 0.6 \\
VII & 0.6 & 0.7 & 1.6 & 1.4 & 4.5 \\
VIII & 1.0 & 1.5 & 0.4 & 2.2 & 0.6 \\
\hline
\end{tabular}

$\mathrm{K}>1.5$ - moisture for all plants excessively wet, $\mathrm{K}$ from 1.01 to 1.5 - sufficient moisture, $\mathrm{K}$ from 0.5 to 1.0 - insufficient moisture, $\mathrm{K}<0.5$ - moisture lower than the requirement of the most crops (drought).

$\mathrm{K}>1,5$ - uwilgotnienie dla wszystkich roślin nadmierne, $\mathrm{K}$ od 1,01 do 1,5 - uwilgotnienie dostateczne, $\mathrm{K}$ od 0,5 do 1,0 - uwilgotnienie niedostateczne, $\mathrm{K}<0,5$ - uwilgotnienie mniejsze od wymagań większości roślin (susza).

The soil compaction in the spring barley plantation was measured in four of the study years, at three depths. The measurements did not prove a significant influence of the MIP complex on changes in the soil compaction measured in the arable layer (Table 3 ). Only in 2008 the application of the PRP SOL was proved to result in a significant decrease in the compaction of the soil layer at a depth of $10 \mathrm{~cm}$, whereas all the other variations, regardless of the research year and measurement depth were statistically insignificant. These significant differences in 2008 may be due to wet weather conditions in April which also Janušauskaite et al. (2013) pointed out in their investigation. The authors proved that varietal and stand density of spring barley effect on photosynthetic rate, transpiration rate, and instantaneous water use efficiency was more strongly expressed in wet conditions (2008) compared to dry conditions (2009). It is worth of

Table 3. Soil compaction at depths of 10, 20 and $30 \mathrm{~cm}$ measured at the spring barley maturity stage (BBCH 83-89) - average for 2007-2011 (kN)

Tabela 3. Zwięzłość gleby na głębokości 10, 20 i $30 \mathrm{~cm}$ oznaczana w fazie dojrzałości jęczmienia jarego (BBCH 83-89) - średnio dla lat 2007-2011 (kN)

\begin{tabular}{|l|c|c|c|}
\hline \multicolumn{1}{c|}{$\begin{array}{c}\text { Treatment } \\
\text { Kombinacja }\end{array}$} & $10 \mathrm{~cm}$ & $20 \mathrm{~cm}$ & $30 \mathrm{~cm}$ \\
\hline Control - Kontrola & 0.66 & 1.07 & 1.36 \\
PRP SOL & 0.81 & 1.05 & 1.46 \\
\hline LSD $_{0.05}-\mathrm{NIR}_{0,05}$ & n.s. & n.s. & n.s. \\
\hline
\end{tabular}

n.s. - not significant statistical difference.

n.s. - różnica nieistotna statystycznie. 
Sulewska, H., Koziara, W., Szymańska, G., Niewiadomska, A., Panasiewicz, K., Ratajczak, K. (2016). Response of spring barley to PRP SOL application as a complex of mineral inducer process (MIP). Nauka Przyr. Technol., 10, 2, \#17. DOI: $10.17306 /$ J.NPT.2016.2.17

mentioning that in 2008 and 2010 at a depth of $20 \mathrm{~cm}$ the decreasing compaction tendency was proved, whereas in 2009 this tendency was observed at a depth of $30 \mathrm{~cm}$. In other studies the application of the PRP SOL in maize caused a significant increase of the soil density but only in deeper layers $(10-30 \mathrm{~cm}$ ) (Sulewska et al., 2013a). On the other hand, when the PRP SOL was applied in rape, there was a significant soil loosening observed in the shallowest layer and the same tendency in both deeper layers as a mean of the research years (Sulewska et al., 2013b). Different responds in the soils under different crops may have been caused by the interaction of their root secretions with the soil environment.

The height of barley plants was evaluated during the four years of the research (Table 4). The application of the PRP SOL did not have significant influence on this feature and the resulting growth in three years did not exceed $0.3 \mathrm{~cm}$. Only in 2011 it was $2.6 \mathrm{~cm}$. Similarly, in the research on maize (Sulewska et al., 2013a) the plants grown with the complex of MIP bioactive compounds did not differ significantly in height from the plants which were traditionally fertilized with phosphorus and potassium. However, the application of the PRP SOL in winter rape led to the average lengthening of the plants by $4.8 \mathrm{~cm}$ during four years, which was statistically proved (Sulewska et al., 2013b).

Table 4. Plant height, leaf greenness index (SPAD), leaf area index (LAI) and grain moisture at harvest of spring barley - average for 2007-2011

Tabela 4. Wysokość roślin, wskaźnik zieloności liści (SPAD), indeks powierzchni liści (LAI) i wilgotność ziarna podczas zbioru jęczmienia jarego - średnio dla lat 2007-2011

\begin{tabular}{|l|c|c|c|c|}
\hline $\begin{array}{c}\text { Treatment } \\
\text { Kombinacja }\end{array}$ & $\begin{array}{c}\text { Plant height } \\
\text { Wysokość roślin } \\
(\mathrm{cm})\end{array}$ & SPAD & LAI & $\begin{array}{c}\text { Grain moisture } \\
\text { Wilgotnośc ziarna } \\
(\%)\end{array}$ \\
\hline Control - Kontrola & $63.4 \mathrm{a}$ & $481.2 \mathrm{~b}$ & $1.99 \mathrm{a}$ & $12.4 \mathrm{a}$ \\
PRP SOL & $64.1 \mathrm{a}$ & $507.6 \mathrm{a}$ & $2.05 \mathrm{a}$ & $12.3 \mathrm{a}$ \\
\hline $\mathrm{LSD}_{0.05}-\mathrm{NIR}_{0,05}$ & n.s. & 21.35 & n.s. & n.s. \\
\hline
\end{tabular}

Values in columns designated with the same letters create homogeneous groups. n.s. - not significant statistical difference.

Wartości w kolumnach oznaczone tymi samymi literami tworzą grupy jednorodne. n.s. - różnica nieistotna statystycznie.

The test based on the positive relationship between the contents of nitrogen and chlorophyll in leaves is an indirect method of plants' nitrogen nutrition status assessment by means of Hydro N-Tester optical device, which can be used in a field without plant damage. The apparatus determines the leaf greenness index in SPAD units, which is the quotient between light absorption at 650 and $940 \mathrm{~nm}$ wavelengths. The light at the wavelength of $650 \mathrm{~nm}$ is absorbed by chlorophyll, whereas the light at the wavelength of $940 \mathrm{~nm}$ by the leaf tissue (Machul and Jadczyszyn, 2005). The SPAD measure is useful for nitrogen top dressing advisory for rice, maize and cereals (Blackmer and Schepers, 1995). This fact is also confirmed by the research conducted by Szulc et al. (2012), where they report that the yield of maize grain depends on such factors as nitro- 
Sulewska, H., Koziara, W., Szymańska, G., Niewiadomska, A., Panasiewicz, K., Ratajczak, K. (2016). Response of spring barley to PRP SOL application as a complex of mineral inducer process (MIP). Nauka Przyr. Technol., 10, 2, \#17. DOI: $10.17306 /$ J.NPT.2016.2.17

gen nutrition status, expressed in SPAD units, and determined at early stages of maize plant development (BBCH 15-16).

The greenness index of barley leaves (SPAD) was assessed on the flag leaf at the end of the flowering stage $(\mathrm{BBCH} 69)$ and at the beginning of grain milk maturity (BBCH 71). During three of the four research years the index increased as a result of the application of the PRP SOL and over the four years the average increase in units was 26.4 SPAD (Table 4). Similarly Janušauskaite (2009) found chlorophyll index in triticale foliage to be significantly influenced by nitrogen fertilization at all growth stages with the significance of the effect in all cases at $99 \%$ probability level. In 2011 , due to the drought which lasted for three months the response of barley plants was different and the greenness index in the control treatment was significantly greater than after the application of the PRP SOL technology. This technology led to increase of the variation of SPAD units amount in the research years, where a favourable growth in its maximum values coincided with a drop in its minimum values (Table 7). Also, in the studies on potatoes (Sulewska et al., 2012), maize (Sulewska et al., 2013a) and winter rape (Sulewska et al., 2013b) a similar plant response type to this fertilization technology was observed.

The leaf area index characterizes the assimilation area, which is capable of PAR absorption and indirectly lead to biomass growth (Lepiarczyk et al., 2005). All green plants contribute to primary production by photosynthetic activity in leaves that play a major role in this process. Therefore, an adequate leaf area is critical to plant constant primary production (Budakli Carpici, 2011). In theory, the higher LAI index value, the greater biomass production and farming yield should be, because according to some authors it is directly related to the LAI value (Czerednik and Nalborczyk, 2000 in Biskupski et al., 2012). According to Jameison et al. (1995), the optimal leaf area index (LAI) for cereal plants at the heading stage should be about 4 . In our study the LAI was assessed during the three years of experiments (2009-2011) (Table 4) and a minimal, statistically insignificant increase in the barley leaf area was proved as a result of the application of the PRP SOL. However, the results observed in the individual years did not show a specific trend, because once in dry conditions there was observed a decrease and twice there was an increase in the value of this trait. These decrease was significant due to the atypical period of time in view of the three-month drought in 2011. Also, in growing of other crops (potatoes, maize, rape) the LAI values were not significantly dependent on the applied fertilization technology (Sulewska et al., 2012, 2013a, 2013b). In the study on winter wheat conducted by Oleksy et al. (2009) the leaf area index (LAI) was significantly correlated with the grain yield both in the intensive and standard farming technology. The correlation at the heading stage was stronger $(0.92-0.93)$ than at the stage of grain filling (0.84-0.87). Also, in our research on spring barley there was a positive and statistically significant correlation between grain yield and LAI index. It equaled to $0.43^{*}$ in the control treatment and to $0.96^{* *}$ when the PRP SOL was applied (Table 5). On the other hand, Biskupski et al. (2007) proved a negative correlation $\left(-0.76^{*}\right)$ between the grain yield and leaf area index in their research on spring wheat. The regression analysis proved a linear dependence between LAI index and grain yield and the application of the PRP SOL strengthened this correlation. As can be seen, when the traditional fertilization with phosphorus and potassium was applied, determination 
Sulewska, H., Koziara, W., Szymańska, G., Niewiadomska, A., Panasiewicz, K., Ratajczak, K. (2016). Response of spring barley to PRP SOL application as a complex of mineral inducer process (MIP). Nauka Przyr. Technol., 10, 2, \#17. DOI: $10.17306 /$ J.NPT.2016.2.17

Table 5. Correlations between spring barley grain yield and leaf area index (LAI)

Tabela 5. Zależności pomiędzy plonem ziarna jęczmienia jarego a indeksem powierzchni liści (LAI)

\begin{tabular}{|l|c|c|c|}
\hline $\begin{array}{c}\text { Treatment } \\
\text { Kombinacja }\end{array}$ & $\begin{array}{c}\text { Regression equation } \\
\text { Równanie regresji }\end{array}$ & $\begin{array}{c}\text { Determination coefficient } \\
\text { Współczynnik determinacji }\end{array}$ & LAI \\
\hline Control - Kontrola & $\mathrm{y}=8.3481 \mathrm{x}+18.575$ & $\mathrm{R}^{2}=0.774$ & $0.880^{*}$ \\
PRP SOL & $\mathrm{y}=10.171 \mathrm{x}+12.819$ & $\mathrm{R}^{2}=0.930$ & $0.964 * *$ \\
\hline
\end{tabular}

*Statistically significant at the level of $\alpha=0.05, * *$ statistically significant at the level of $\alpha=0.01$.

*Istotny statystycznie na poziomie $\alpha=0,05, * *$ istotny statystycznie na poziomie $\alpha=0.01$.

coefficients equaled to 0.77 , whereas it amounted to 0.93 in the treatments fertilized with the PRP SOL (Table 5). This analysis points to a very strong, yield-stimulating influence of the area of leaves. One unit of LAI increased grain yield by $8.35 \mathrm{dt} \cdot \mathrm{ha}^{-1}$ in the control treatment and by $10.17 \mathrm{dt} \cdot \mathrm{ha}^{-1}$ when the PRP SOL was applied.

The barley grain moisture during harvesting was not significantly dependent on the application of the PRP SOL (Table 4). When the fertilizer under discussion was applied, the moisture dropped by $0.1 \%$ on average. It is necessary to stress the fact that in none of the five years of the research the influence of the fertilizer on this trait was statistically proved. In the other studies of Sulewska et al. (2013b) the application of a complex of MIP bioactive compounds in maize extended the plant vegetation, which was manifested by significantly greater (by $0.5 \%$ on average) grain moisture at harvest. Similarly, when the PRP SOL was applied in rape growing, the grain moisture increased by $0.7 \%$ on average, but this observation was not statistically proved (Sulewska et al., 2013b).

In the study by Dubis et al. (2012) after the application of a similar dose of nitrogen barley grain yield reached $6.72 \mathrm{dt} \cdot \mathrm{ha}^{-1}$ and was significantly higher than in our research (Table 6). In that study spring barley was grown on much better soil of the good wheat complex, which explains such a big difference in the yield level. Also, in the studies by

Table 6. Spring barley grain yield and yield components - average for 2007-2011

Tabela 6. Plon ziarna jęczmienia jarego oraz komponenty plonowania - średnio dla lat 2007-2011

\begin{tabular}{|l|c|c|c|c|c|}
\hline \multicolumn{1}{|c|}{$\begin{array}{c}\text { Treatment } \\
\text { Kombinacja }\end{array}$} & $\begin{array}{c}\text { Grain yield } \\
\text { Plon ziarna } \\
\left.\left(\mathrm{dt}^{-1}\right)^{-1}\right)\end{array}$ & $\begin{array}{c}\text { Spikes number } \\
\text { per } 1 \mathrm{~m}^{2} \\
\text { Liczba kłosów } \\
\text { na } 1 \mathrm{~m}^{2}\end{array}$ & $\begin{array}{c}\text { Grain number } \\
\text { per spike } \\
\text { Liczba ziarn } \\
\text { w kłosie }\end{array}$ & $\begin{array}{c}\text { TGW } \\
\text { MTZ } \\
(\mathrm{g})\end{array}$ & $\begin{array}{c}1 \mathrm{hl} \text { weight } \\
\text { Masa } 1 \mathrm{hl} \\
(\mathrm{kg})\end{array}$ \\
\hline Control - Kontrola & $35.40 \mathrm{a}$ & $553.6 \mathrm{a}$ & $20.1 \mathrm{a}$ & $44.3 \mathrm{a}$ & $60.8 \mathrm{a}$ \\
PRP SOL & $35.42 \mathrm{a}$ & $525.5 \mathrm{a}$ & $20.6 \mathrm{a}$ & $44.7 \mathrm{a}$ & $59.1 \mathrm{a}$ \\
\hline $\mathrm{LSD}_{0.05}-\mathrm{NIR}_{0,05}$ & n.s. & n.s. & n.s. & n.s. & n.s. \\
\hline
\end{tabular}

Values in columns designated with the same letters create homogeneous groups. n.s. - not significant statistical difference.

Wartości w kolumnach oznaczone tymi samymi literami tworzą grupy jednorodne. n.s. - różnica nieistotna statystycznie. 
Sulewska, H., Koziara, W., Szymańska, G., Niewiadomska, A., Panasiewicz, K., Ratajczak, K. (2016). Response of spring barley to PRP SOL application as a complex of mineral inducer process (MIP). Nauka Przyr. Technol., 10, 2, \#17. DOI: $10.17306 /$ J.NPT.2016.2.17

Liszewski et al. (2011) in comparison with the control treatment a significant increase in the yield of malting barley grain was observed in the treatment fertilized with $\mathrm{N}$ doses of $40-60 \mathrm{~kg} \cdot \mathrm{ha}^{-1}$, and this was a result of the higher number of productive spikes per area unit. This level of optimal $\mathrm{N}$ doses for malting barley is also confirmed by the other authors (Błażewicz and Liszewski, 2003; Koziara et al., 1998; Małecka and Blecharczyk, 2008).

In all study years the grain yield of barley was also lower than in the model used in the investigations by COBORU (Research Centre for Cultivar Testing) (COBORU, 2010, 2012). Under conditions of two different cultivation technologies the yield of barley grain was similar. In our study, after the application of the PRP SOL a not significant increase of $0.02 \mathrm{dt} \cdot \mathrm{ha}^{-1}$ (Table 6) was observed. In general, the PRP SOL technology enables replacement of the phosphorus and potassium fertilization in spring barley growing. However, as a consequence of the weather conditions in 2010 the barley grain yield in this technology decreased by $3.2 \mathrm{dt} \cdot \mathrm{ha}^{-1}$ in comparison with the control treatment. However, it is difficult to show the direct cause of such a considerable decrease of barley yield. The fertilization of the other crops with PRP SOL also resulted in yield decrease in some years. Application of this fertilization technology in potato was very favourable due to an increasing tendency of tubers yield in the four research years, besides a slight decrease in one of the years (by $4 \mathrm{dt} \cdot \mathrm{ha}^{-1}$ ) (Sulewska et al., 2012). In maize during the four study years the increase in grain yield ranged from 6.1 to $11.9 \mathrm{dt} \cdot \mathrm{ha}^{-1}$, but in 2011 with dry spring year it decreased by $10.7 \mathrm{dt} \cdot \mathrm{ha}^{-1}$ (Sulewska et al., 2013a). On the other hand, the response of winter rape to the fertilizer was not favourable, due to the decrease of grain yield in three of five research years and decrease ranged from 0.19 to $8.81 \mathrm{dt} \cdot \mathrm{ha}^{-1}$. In the other two years the fertilizer increased grain yield by 1.16 and $1.42 \mathrm{dt} \cdot \mathrm{ha}^{-1}$ (Sulewska et al., 2013b).

The application of the PRP SOL fertilizer in barley led to a greater variation in grain yield between individual years than in the control treatment (Table 7). The variation resulted from the increase of the range between minimum and maximum values of yield in PRP SOL treatment.

The number of spikes per square meter did not vary significantly due to the use of the PRP SOL (Table 6). However, in three of the five research years when the PRP SOL was applied a slight increasing tendency in the number of spikes was observed, but in 2009 and 2011 a decrease was noted. The number of spikes per square meter was the only yield component whose value decreased after the application of the fertilizer under investigation. On the other hand, the application of the PRP SOL stabilized the variation in this trait between study years, as can be seen from the lower value of the coefficient of variation than in the control treatment (Table 7). Apart from that, PRP SOL favourable increased the minimum values of the trait what coincided with a decrease of its maximum value.

The application of the PRP SOL technology led to a mean increase of the number of grains per spike by 0.5 , however it was not statistically proven (Table 6 ). Such a favourable tendency was observed in four of the five research years and the increase fluctuated from 0.3 to 2.1 grains per spike. Only the conditions in 2010 caused a decreasing tendency in this number. The application of the PRP SOL in spring barley reduction the variability of this trait between the research years, causing a simultaneous increase of its minimum and maximum values (Table 7). For number of grains per spike SD indicates greater variation in PRP SOL treatments. 
Sulewska, H., Koziara, W., Szymańska, G., Niewiadomska, A., Panasiewicz, K., Ratajczak, K. (2016). Response of spring barley to PRP SOL application as a complex of mineral inducer process (MIP). Nauka Przyr. Technol., 10, 2, \#17. DOI: $10.17306 /$ J.NPT.2016.2.17

Table 7. Statistical characteristics of selected spring barley traits - average for 2007-2011

Tabela 7. Charakterystyki statystyczne wybranych cech jęczmienia jarego - średnio dla lat 20072011

\begin{tabular}{|c|c|c|c|c|c|}
\hline \multirow{2}{*}{$\begin{array}{l}\text { Trait } \\
\text { Cecha }\end{array}$} & \multirow{2}{*}{$\begin{array}{l}\text { Treatment } \\
\text { Kombinacja }\end{array}$} & \multicolumn{2}{|c|}{ Values - Poziomy } & \multirow{2}{*}{$\begin{array}{c}\text { Standard } \\
\text { deviation } \\
\text { Odchylenie } \\
\text { standardowe }\end{array}$} & \multirow{2}{*}{$\begin{array}{l}\text { Coefficient } \\
\text { of variation } \\
\text { Współczynnik } \\
\text { zmienności } \\
(\%)\end{array}$} \\
\hline & & $\min$. & $\max$ & & \\
\hline \multirow[t]{2}{*}{ SPAD } & Control - Kontrola & 415.6 & 551.8 & 74.0 & 15.5 \\
\hline & PRP SOL & 346.8 & 606.7 & 116.4 & 22.9 \\
\hline Grain yield & Control - Kontrola & 13.1 & 51.3 & 15.8 & 15.7 \\
\hline $\begin{array}{l}\text { Plon ziarna } \\
\left(\mathrm{dt} \cdot \mathrm{ha}^{-1}\right)\end{array}$ & PRP SOL & 13.3 & 48.1 & 15.1 & 16.5 \\
\hline \multirow{2}{*}{$\begin{array}{l}\text { Spikes number per } 1 \mathrm{~m}^{2} \\
\text { Liczba kłosów na } 1 \mathrm{~m}^{2}\end{array}$} & Control - Kontrola & 137.0 & 812.3 & 256.3 & 46.3 \\
\hline & PRP SOL & 138.3 & 720.8 & 234.8 & 44.7 \\
\hline \multirow{2}{*}{$\begin{array}{l}\text { Grain number per spike } \\
\text { Liczba ziarn w kłosie }\end{array}$} & Control - Kontrola & 17.0 & 22.3 & 1.9 & 17.7 \\
\hline & PRP SOL & 17.4 & 24.1 & 2.7 & 17.4 \\
\hline TGW & Control - Kontrola & 40.8 & 47.4 & 2.9 & 6.7 \\
\hline $\begin{array}{l}\text { MTZ } \\
(\mathrm{g})\end{array}$ & PRP SOL & 42.2 & 48.2 & 2.4 & 5.4 \\
\hline $1 \mathrm{hl}$ weight & Control - Kontrola & 47.6 & 67.2 & 7.9 & 12.9 \\
\hline $\begin{array}{l}\text { Masa } 1 \text { hl } \\
(\mathrm{kg})\end{array}$ & PRP SOL & 47.8 & 64.4 & 6.6 & 11.1 \\
\hline
\end{tabular}

On average of the five research years PRP SOL did not significantly affect barley's thousand grain weight. There was only a slight increase, by $0.4 \mathrm{~g}$, observed in this value (Table 6). After the application of the fertilizer in the individual years the variation tendencies did not show a specific direction of the trend. Only in 2007 weather conditions enabled a significant increase in the TGW, by $3.9 \mathrm{~g}$ on average, in consequence of the application of the PRP SOL technology. On the other hand, during the other years of the research the variation was minimal. Decreased SD and CV indicates that the application of the PRP SOL stabilized the TGW value and favourably increased both its minimum and maximum values (Table 7).

Barczak and Majcherczak (2008) used the analysis of correlation and proved the strongest relationship between grain yield of spring barley grains and the density of spikes. The second most significant factor decisive to the grain yield was the number of grains per spike. In their investigations sulphur fertilization did not noticeably change the dependence of the yield on its components. In our research, the yield obtained from the plants which were traditionally fertilized with phosphorus and potassium (the control treatment) was significantly correlated with the number of grains per spike. But when the PRP SOL was applied, grain yield was not significantly affected by the yield components (Table 8). In turn, Janušauskaitė et al. (2009) using polynomial correlation model found a strong and significant correlation between the yield of spring barley varieties and foliage chlorophyll index measured at various growth stages $(\mathrm{R}=$ 
Sulewska, H., Koziara, W., Szymańska, G., Niewiadomska, A., Panasiewicz, K., Ratajczak, K. (2016). Response of spring barley to PRP SOL application as a complex of mineral inducer process (MIP). Nauka Przyr. Technol., 10, 2, \#17. DOI: $10.17306 /$ J.NPT.2016.2.17

Table 8. Correlation coefficients between spring barley grain yield and its components Tabela 8. Współczynniki korelacji między plonem ziarna jęczmienia jarego i jego składowymi

\begin{tabular}{|l|c|c|c|c|}
\hline $\begin{array}{c}\text { Treatment } \\
\text { Kombinacja }\end{array}$ & TGW & $\begin{array}{c}\text { Grain number } \\
\text { per spike } \\
\text { Liczba ziarn } \\
\text { w kłosie }\end{array}$ & $\begin{array}{c}\text { Spikes number } \\
\text { per } 1 \mathrm{~m}^{2} \\
\text { Liczba kłosów } \\
\text { na } 1 \mathrm{~m}^{2}\end{array}$ & LAI \\
\hline Control - Kontrola & -0.343 & $0.757 * *$ & 0.096 & 0.335 \\
PRP SOL & -0.558 & 0.474 & 0.344 & $0.629 *$ \\
\hline
\end{tabular}

*Value statistically significant at the level of $\alpha=0.05$.

**Value statistically significant at the level of $\alpha=0.01$.

*Wartość istotna statystycznie na poziomie $\alpha=0,05$.

**Wartość istotna statystycznie na poziomie $\alpha=0,01$.

$0.612 * *)$. In our study such a strong and significant relationship between the yield of spring barley and leaf greenness index was obtained when the PRP SOL was applied.

In the synthesis for 2007-2011 the weight of $1 \mathrm{hl}$ did not significantly depend on the application of the PRP SOL (Table 6). In consequence, the value of this trait tended to decrease (by $1.7 \mathrm{~kg} \cdot \mathrm{hl}^{-1}$ ), which was favourable for brewing. This trend was observed in three of the five research years and the drops in the value of the trait under discussion ranged from $1.0 \mathrm{~kg} \cdot \mathrm{hl}^{-1}$ (2008) to $6.9 \mathrm{~kg} \cdot \mathrm{hl}^{-1}$ (2009). On the other hand, in 2007 and 2011 the opposite tendency was observed. PRP SOL increased the weight of $1 \mathrm{hl}$ by 0.1 and $0.2 \mathrm{~kg}$, respectively. The application of the PRP SOL limited the variability of this trait. It also slightly increased its minimum but decreased its maximum value (Table 7).

The application of the PRP SOL technology in spring barley significantly increased the share of the largest grain fractions with the diameters exceeding $2.75 \mathrm{~mm}$ by $3.1 \%$, which is favourable to brewing (Table 9). On the other hand, the share of finer grain fractions of $2.5 \mathrm{~mm}$ and $2.25 \mathrm{~mm}$ diameter and smaller grains decreased respectively by $0.3 \%, 1.7 \%$ and $1.1 \%$.

Table 9. Share of individual spring barley grain fractions - average for 2007-2011 (\%)

Tabela 9. Udział poszczególnych frakcji ziarna jęczmienia jarego - średnio dla lat 2007-2011 (\%)

\begin{tabular}{|l|c|c|c|c|}
\hline \multirow{2}{*}{$\begin{array}{c}\text { Treatment } \\
\text { Kombinacja }\end{array}$} & $2.75 \mathrm{~mm}$ & $2.5 \mathrm{~mm}$ & $2.25 \mathrm{~mm}$ & $\begin{array}{c}\text { Diameters of sieve meshes }- \text { Średnice oczek sit } \\
\text { pozostałe }\end{array}$ \\
\cline { 2 - 5 } & $30.4 \mathrm{~b}$ & $17.2 \mathrm{a}$ & $13.6 \mathrm{a}$ & $38.8 \mathrm{a}$ \\
Control - Kontrola & $33.5 \mathrm{a}$ & $16.9 \mathrm{~b}$ & $11.9 \mathrm{~b}$ & $37.7 \mathrm{a}$ \\
\hline PRP SOL & 2.74 & 0.25 & 1.03 & n.s. \\
\hline $\mathrm{LSD}_{0.05}-\mathrm{NIR}_{0,05}$ &
\end{tabular}

Values in columns designated with the same letters create homogeneous groups. n.s. - not significant statistical difference.

Wartości w kolumnach oznaczone tymi samymi literami tworzą grupy jednorodne. n.s. - różnica nieistotna statystycznie. 
Sulewska, H., Koziara, W., Szymańska, G., Niewiadomska, A., Panasiewicz, K., Ratajczak, K. (2016). Response of spring barley to PRP SOL application as a complex of mineral inducer process (MIP). Nauka Przyr. Technol., 10, 2, \#17. DOI: $10.17306 /$ J.NPT.2016.2.17

\section{Conclusions}

1. The technology applying an MIP complex of bioactive compounds can replace the traditional fertilization of spring barley plantations with phosphorus and potassium without grain yield losses.

2. PRP SOL can be particularly useful in malting barley due to the favourable increase of the share of lush grain fractions (larger than $2.5 \mathrm{~mm}$ ) and simultaneous decrease of the share of smaller caryopses and due to the fact that the weight of $1 \mathrm{hl}$ tends to decrease whereas the TGW tends to increase.

\section{References}

Barczak, B., Majcherczak, E. (2008). Effect of varied fertilization with sulphur on selected spring barley yield structure components. J. Cent. Eur. Agric., 9, 4, 777-784.

Biskupski, A., Kaus, A., Włodek, S., Pabin, J. (2007). Zróżnicowane nawożenie azotem a plonowanie i wybrane wskaźniki architektury łanu kilku odmian pszenicy jarej. Inż. Roln., 11, 91, 3, 29-36.

Biskupski, A., Włodek, S., Sekutowski, T., Smagacz, J. (2012). Effect of tillage systems and straw fertilization on the grain yield and selected indicators of cereals and physical properties of soil. Acta Sci. Pol. Agric., 11, 3, 17-29.

Blackmer, T. M., Schepers, J. S. (1995). Use of chlorophyll meter to monitor nitrogen status and schedule fertigation for corn. J. Prod. Agric., 8, 56-60.

Błażewicz, J., Liszewski, M. (2003). Ziarno jęczmienia jarego nagiego odmiany 'Rastik' jako surowiec do produkcji słodów typu pilzneńskiego. Acta Sci. Pol. Technol. Aliment., 2, 1, 6374.

Budakli Carpici, E. (2011). Changes in leaf area index, light interception, quality and dry matter yield of an abandoned rangeland as affected by the different levels of nitrogen and phosphorus fertilization. Turk. J. Field Crops, 16, 2, 117-120.

COBORU. (2010). Lista opisowa odmian roślin uprawnych. Słupia Wielka: COBORU.

COBORU. (2012). Lista opisowa odmian roślin uprawnych. Słupia Wielka: COBORU.

Dobrzański, B., Zawadzki, S. (1995). Gleboznawstwo. Warszawa: PWRiL.

Dubis, B., Hłasko-Nasalska, A., Hulanicki, P. (2012). Yielding and malting quality of spring barley cultivar Prestige depending on nitrogen fertilisation. Acta Sci. Pol. Agric., 11, 3, 45-56.

FAO. (2006). Guidelines for soil description. Rome: Food and Agriculture Organization of the United Nations.

Hüttl, R. F., Fischer, T. H. (2004). Expert opinion concerning the action of the product PRP Boden (substratum PRP) on the field crop. Cottbus: Brandenburg Technical University.

Jameison, P. D., Martin, R. J., Francis, G. S., Wilson, D. R. (1995). Drought effects on biomass production and radiation - use efficiency in barley. Field Crops Res., 43, 77-86.

Janušauskaitė, D. (2009). Tręšimo intensyvumo ịtaka vasarinių kvietrugių produktyvumui ir lapijos chlorofilo indeksui. Žemdir.-Agric., 96, 4, 110-123.

Janušauskaite, D., Auškalnienè, O., Feizienė, D., Feiza, V. (2013). Response of common barley (Hordeum vulgare L.) physiological parameters to agricultural practices and meteorological conditions. Žemdir.-Agric., 100, 2, 127-136.

Janušauskaitè, D., Auškalnienė, O., Pšibišauskienè, G. (2009). Skirtingo tankumo vasariniu miežių pasèlio lapijos chlorofilo indeksas ir jo ryšys su derliumi. Žemdir.-Agric., 96, 4, 124 138. 
Sulewska, H., Koziara, W., Szymańska, G., Niewiadomska, A., Panasiewicz, K., Ratajczak, K. (2016). Response of spring barley to PRP SOL application as a complex of mineral inducer process (MIP). Nauka Przyr. Technol., 10, 2, \#17. DOI: $10.17306 /$ J.NPT.2016.2.17

Koziara, W., Borówczak, F., Grześ, S. (1998). Elementy struktury plonu jęczmienia jarego w zależności od deszczowania, nawożenia azotem i technologii uprawy. Pam. Puław., 112, $115-120$.

Krzywy, E. (2008). Ocena wpływu substancji czynnej PRP na kształtowanie żyzności i urodzajności gleb. In: Dla rolnictwa czystego i produktywnego (pp. 31-32). Warszawa: PRP Polska.

Lepiarczyk, A., Kulig, B., Stępniak, K. (2005). Wpływ uproszczonej uprawy roli i przedplonu na plonowanie oraz kształtowanie LAI wybranych odmian pszenicy ozimej w płodozmianie zbożowym. Fragm. Agron., 22, 2, 98-105.

Lipski, S. (2008). Żywienie roślin czy nawożenie gleby? In: Dla rolnictwa czystego i produktywnego (pp. 3-6). Warszawa: PRP Polska.

Liszewski, M., Błażewicz, J., Kozłowska, K., Zembold-Guła, A., Szwed, Ł. (2011). Wpływ nawożenia azotem na cechy rolnicze ziarna jęczmienia browarnego. Fragm. Agron., 28, 1, 4049.

Machul, M., Jadczyszyn, T. (2005). Suitability of relative chlorophyll content index to assess maize nitrogen nutrition status. Pam. Puław., 140, 175-185.

Mahler, R. L., Guy, S. O. (2007). Spring barley. Northern Idaho fertilizer guide. Moscow: University of Idaho College of Agricultural and Life Sciences. Obtained from: http://www.cals.uidaho.edu/edComm/pdf/CIS/CIS0920.pdf [Accessed March 5, 2014].

Maikštėnienè, L., Maikštėnienė, S. (2011). The effect of agronomic and meteorological factors on the yield of main and catch crops. Žemdir.-Agric., 98, 3, 235-244.

Małecka, I., Blecharczyk, A. (2008). Effect of tillage systems, mulches and nitrogen fertilization on spring barley (Hordeum vulgare). Agron. Res., 6, 2, 517-529.

Oleksy, A., Szmigiel, A., Kołodziejczyk, M. (2009). Efekty stosowania PRP SOL w kukurydzy uprawianej na ziarno. Fragm. Agron., 26, 4, 120-131.

Ram, H., Malik, S. S., Dhaliwal, S. S., Kumar, B., Singh, Y. (2015). Growth and productivity of wheat affected by phosphorus solubilizing fungi and phosphorus levels. Plant Soil Environ., $61,3,122-126$.

Šarauskis, E., Masilionytè, L., Andriušis, A., Jakštas, A. (2013). The force needed for breaking and cutting of winter wheat and spring barley straw. Žemdir.-Agric., 100, 3, 269-276.

Sulewska, H., Koziara, W., Szymańska, G., Niewiadomska, A., Majchrzak, L., Panasiewicz, K. (2012). Potatoes reaction on PRP SOL fertilisation. J. Res. Appl. Agric. Eng., 57, 4, 116-121.

Sulewska, H., Szymańska, G., Śmiatacz, K., Koziara, W., Niewiadomska, A. (2013a). Efekty stosowania PRP SOL w kukurydzy uprawianej na ziarno. J. Res. Appl. Agric. Eng., 58, 4, 161-166.

Sulewska, H., Śmiatacz, K., Sitek, A., Szymańska, G., Panasiewicz, K. (2013b). Ocena plonowania rzepaku ozimego przy zastosowaniu technologii PRP SOL. J. Res. Appl. Agric. Eng., 58, 4, 167-173.

Szulc, P., Bocianowski, J., Rybus-Zając, M. (2012). The effect of soil supplementation with nitrogen and elemental sulphur on chlorophyll content and grain yield of maize (Zea mays L.). Žemdir.-Agric., 99, 3, 247-254.

\section{REAKCJA JECZZMIENIA JAREGO NA STOSOWANIE PRP SOL JAKO KOMPLEKSU BIOAKTYWNYCH ZWIĄZKÓW MINERALNYCH (MIP)}

Streszczenie. Stosowanie kompleksu bioaktywnych związków mineralnych (MIP) w postaci PRP SOL ma na celu poprawę właściwości gleby poprzez odblokowanie potencjału składników w niej zgromadzonych i udostępnienie ich roślinie. PRP SOL służy do nawożenia gleby, a nie żywienia 
Sulewska, H., Koziara, W., Szymańska, G., Niewiadomska, A., Panasiewicz, K., Ratajczak, K. (2016). Response of spring barley to PRP SOL application as a complex of mineral inducer process (MIP). Nauka Przyr. Technol., 10, 2, \#17. DOI: $10.17306 /$ J.NPT.2016.2.17

roślin. Badania nad plonowaniem jęczmienia jarego po zastosowaniu PRP SOL prowadzono w latach 2007-2011 na polach Zakładu Doświadczalno-Dydaktycznego Gorzyń, Stacja w Złotnikach. Celem badań było porównanie efektów dwóch technologii nawożenia jęczmienia jarego: z użyciem kompleksu bioaktywnych związków mineralnych w postaci nawozu PRP SOL oraz standardowej z nawożeniem fosforowo-potasowym. Pięcioletnie badania pozwoliły stwierdzić, że tradycyjne nawożenie jęczmienia jarego fosforem i potasem można zastąpić technologią wykorzystującą kompleks MIP, a uzyskiwane plony ziarna są zwykle podobne. W jednym (2007) z pięciu lat prowadzenia badań uzyskano istotny wzrost (o 3,7 dt $\left.\cdot \mathrm{ha}^{-1}\right)$, a w innym (2010) spadek (o $3,2 \mathrm{dt} \cdot \mathrm{ha}^{-1}$ ) plonu jako wynik wprowadzenia tego nawozu. Nawóz PRP SOL może być szczególnie przydatny w uprawie jęczmienia browarnego $\mathrm{z}$ uwagi na korzystny wzrost udziału frakcji ziarna dorodnego - powyżej $2,5 \mathrm{~mm}$, przy równoczesnym spadku udziału ziarniaków drobniejszych, a także pojawiającej się tendencji do spadku masy hektolitra, i wzroście wartości MTZ.

Słowa kluczowe: nawóz PRP SOL, jęczmień jary, plon ziarna, LAI, SPAD, komponenty plonowania

Corresponding address - Adres do korespondencji:

Hanna Sulewska, Katedra Agronomii, Uniwersytet Przyrodniczy w Poznaniu, ul. Dojazd 11, 60-632 Poznań, Poland, e-mail: sulewska@up.poznan.pl

Accepted for publication - Zaakceptowano do opublikowania: 19.10.2015

For citation - Do cytowania:

Sulewska, H., Koziara, W., Szymańska, G., Niewiadomska, A., Panasiewicz, K., Ratajczak, K. (2016). Response of spring barley to PRP SOL application as a complex of mineral inducer process (MIP). Nauka Przyr. Technol., 10, 2, \#17. DOI: 10.17306/J.NPT.2016.2.17 